ISSN:2528-9527

E-ISSN : 2528-9535

YIl Year: 7

Cilt Volume:7

Sayı Issue : 12

\title{
Belediyelerde Sosyal Politika Uygulamaları Ve Pendik Belediyesi Örneği
}

\author{
Orhan Koçak $^{*}$ - Hüseyin Arslan ${ }^{* *}$-Serkan Eti ${ }^{* * *}$ \\ * Doç. Dr., İstanbul Üniversitesi, Sağlık Bilimleri Fakültesi, Sosyal Hizmet Bölümü. İstan- \\ bul/Türkiye \\ E-Posta: orhan.kocak@istanbul.edu.tr ORCID: 0000-0002-0281-8805 \\ ** Yrd. Doç. Dr., İstanbul Ticaret Üniversitesi, İstanbul/Türkiye \\ E-Posta: harslan@ticaret.edu.trＯORCID: 0000-0002-2190-2607 \\ ${ }^{* * *}$ Öğr. Gör. Medipol Üniversitesi,. İstanbul/Türkiye \\ E-Posta: serkaneti@yandex.comＯRCID: 0000-0002-4791-4091
}

Öz

Sosyal politikalar genelde merkezi hükümetler tarafindan planlanır ve ağırlıklı olarak yerel yönetimler tarafından uygulanır. Son yıllarda sosyal politikaların yerelleşmesi daha da önem kazanmıştır. Bunun sebebi ise halkın sorunların yerel yönetimlerin daha iyi tespit edebilmesi ve erişebilmeleri olarak görülebilir. Yerel yönetimlerden biri olan belediyeler temel kentsel hizmetler sağlayan kurumlardır. Bunun yaninda halk belediyelerden sosyal sorunlarn ile de ilgilenmelerini beklemektedir. Sosyal belediyecilikte sadece hizmetler üzerine değil, halkın sosyal sorunlarıla da ilgilenilmektedir. Bu anlamda, belediyelerin sosyal sorunlarm çözümü için merkezi yönetimden daha fazla maddi kaynă̆a ve desteğe ihtiyaçları vardır. Bu çalışmada sosyal belediyeciliğin ne olduğu araştırılmış olup, çalışmanın birinci kısmında sosyal politika ve yerel yönetim hakkında literatür taraması yapılmıştır. Çalışmanın ikinci kısmında, belediyecilik ile ilgili yasal düzenlemeler incelenmiştir. Çalışmanın üçüncü kısmında, belediye ve sosyal politika ilişkisi araştırılmıştır. Son kısımda ise, Istanbul'un önemli bir ilçesi olan Pendik'te sosyal belediyecilik uygulamaları değerlendirilmiştir.

Anahtar Kelimeler: Sosyal politika, belediye, sosyal belediyecilik 
ISSN:2528-9527

E-ISSN : 2528-9535

YIl Year: 7

Cilt Volume:7

Sayı Issue : 12

Uluslararası Toplum Araştırmaları Dergisi

International Journal of Society Researches

Haziran June 2017

Makalenin Geliş Tarihi Received Date: 09/05/2017

Makalenin Kabul Tarihi Accepted Date: 09/06/2017

\title{
Social Policy Applications In Municipalities and Pendik Municipality Sample
}

\begin{abstract}
Social policies are usually planned by central governments and implemented by local governments. In recent years, the decentralization of social policies has come into prominence. Because local governments can determine the problem of the people and easily reach and solve them. Municipalities provide basic city services, but people want municipality to interest in their social problems. A social municipality not only works for services but also works on social problems of the people. In this paper, what a social municipality has been investigated. The municipality needs more fund to solve the social problems and central government must help the municipalities more in this aspect. In the first part of the article, what do social policy and local government mean and history of them are described. In the second part of the article, local government and its duty in law have been examined. In the third part of the article, the relation between the municipality and social policy has been analyzed. In the last part, social municipality applications in Pendik that is an important district of Istanbul has been studied.
\end{abstract}

Key Words: Social policy, municipality, social municipality 


\section{Giriş}

Sosyal kelimesi toplumla ilgili, birden fazla insanın oluşturduğu insan toplulukları ile ilgilidir. Ancak sosyal politika konularında sosyal kelimesi hangi başka bir kelimenin önüne gelirse bu kelimeye insani bir boyut kazandırır. Bu anlamda kullanılan sosyal kelimesi "karşılıklı yardım ve dayanışma anlayışı ile birlikte hareket etme" anlamını taşır (Alper, 2004: 3). $\mathrm{Bu}$ yardımlaşma ve dayanışmanın temelinde toplum içinde zayıf olanı, güçsüz olanı koruma, onu muhtaçlıktan kurtarma amacı vardır. Bu manada sosyal adalet, sosyal devlet, sosyal güvenlik ve sosyal belediyecilik bahsedilen anlama sahip kavramlar olarak ortaya çıkmıştır.

Sosyal politika kavramı 19. yüzyılda sanayileşmenin sonuçlarından biri olarak ortaya çıkmış ve İkinci Dünya Savaşı'na kadar işçi-işveren ilişkilerini inceleyen dar kapsamda ele alınmıştır. Sanayi devrimi ile birlikte kentlerin nüfusu artmış ancak özellikle İkinci Dünya savaşı sonrası bu nüfus artışı çok hızlı olmuştur. Bu nüfus artışına bağlı olarak sosyal politika kapsamında ele alınabilecek sorunlar artmış ve sosyal politika, bireylerin toplumsal yaşamda karşılaştıkları veya karşılaşabilecekleri tüm sorunların alanına ulaşmıştır (Güven, 1995: 11). Daha açık bir ifade ile sosyal politika, başlangıçta işçilerin korunması ve işçi-işveren arasındaki çatışmanın giderilmesi için başlamış, daha sonra toplumun tüm bireylerini kapsayacak bir genişliğe ulaşarak devletin uyguladığı vergi ve ücret politikalarından sosyal yardımlara, eğitim ve sağlık politikalarından çocuk yuvaları ve huzur evlerine kadar birçok uygulama ve hizmetin yer aldığı bir olgu olmuştur (Koray-Topçuoğlu, 1995: 22).

Son 20-30 yıl içinde ekonomik gelişmeler, küreselleşmenin artması ve hatta komünizmin yıkılması sonuçlarına bağlı olarak belediyelerin yönetim anlayışlarında değişiklikler meydana getirmiştir (Andrew Goldsmıth, 1998: 101). Bu değişikliklere bağlı olarak kamu yönetiminde modern işletme anlayışı içinde sosyal sorumluluk odak noktası haline gelmiştir (Yllmazer, 2010: 311). Kamu yönetiminde yerel yönetimin bir birimi olan belediyeler yerel kentsel hizmetlerin yanında sosyal sorumluluk anlayışının gereği olarak, halkın sosyal durumları ile de ilgilidirler. Belediyeler son yillarda görevlerini sadece yol, su ve kanalizasyondan ibaret görmemektedir. Bunların yanı sıra kent sakinlerinin sosyal, kültü- 
rel, sportif ve benzeri ihtiyaçlarını da dikkate almaktalar ve gerekli hizmetleri mali yapılarının elverdiği ölçüde sunmaktadırlar. Bu belediyecilik anlayışı sosyal belediyecilik olarak adlandırılmaktadır. Ayrıca "Sosyal Belediyecilik", Akdoğan tarafından şöyle tanımlanmakta: "Mahalli idareye sosyal alanlarda planlama ve düzenleme işlevi yükleyen, bu çerçevede kamu harcamalarını konut, sağlık, eğitim ve çevrenin korunması alanlarını kapsayacak şekilde sosyal amaca yönlendiren; muhtaçlara yardım yapılması ve sosyal dayanışmanın tesis edilmesi ile sosyo-kültürel faaliyetlerin gerçekleştirilebilmesi için gerekli olan altyapı yatırımlarını üstlenen; bireyler ve toplumsal kesimler arasında zayıflayan sosyal güvenlik ve adalet mefhumunu güçlendirmeye yönelik olarak mahallî idarelere sosyal kontrol işlevleri yükleyen bir modeldir" (Akdoğan, 2002).

Sosyal politika uygulama alanları içinde sorunların çözülmesinde en etkin ve güçlü kurum devlettir. Yerel yönetimler, devletin işleyişi içinde halka en yakın kuruluşlar olarak, mahalli sorunların tespit edilmesinde, sosyal politikalar oluşturulmasında ve bu politikaların uygulanmasında önemli yere sahiptirler. Özellikle refah devleti kavramının ortaya çıktığı İkinci Dünya savaşından sonra bu kapsamda ele alınan sorunların çözümünde belediyelerin sosyal yardım ve sosyal hizmet uygulamaları önemini artırmıştır.

\section{Sosyal Politika}

Sosyal politikanın doğuşu 19. yüzyılda işçi sınıfı odaklı çalışmalar ile olmuştur. Sanayi devrimi sırasında uygulanan iktisat politikaları sonucunda, bu kesimin çalışma ve yaşam koşulları ağırlaşmıştır. Ücretler düşmüş, çalışma hayatına kadınlar ve çok küçük yaşta çocuklar girmiştir. Bunların sonucunda toplumsal düzen ve sosyal denge bozulmuştur. Sosyal politika uygulamalarının temelleri böyle bir ortamda atılmıştır. Çalışma koşullarının iyileştirilmesi, sosyal güvenlik (Koray, 1995: 4), çalışma hayatındaki kadın ve çocuklar gibi konular sosyal politikanın temel konularıdır.

İkinci dünya savaşına kadar geçen zaman zarfında sosyal politikanın ilgilendiği konular işçi-işveren arasındaki anlaşmazlıklar ve çatışmalardı. İkinci dünya savaşından sonra "Refah devleti" kavramıyla birlikte sosyal 
politikanın ilgilendiği konular gelişmiştir (Güven, 1995: 12). Sosyal refahı etkileyen her konu ve sorun sosyal politikanın ilgi alanına girmiştir. Sosyal politika çok çeşitli tanımlar yapılan bir bilim dalıdır. Ancak bütün tarifleri iki kategori altına toplamak mümkündür. Bunlar dar anlamda sosyal politika ve geniş anlamda sosyal politika.

19. yüzyılda sanayi devriminden sonra ortaya çıkan, işçi sorunlarını çözmeye yönelik politikaları içeren sosyal politika anlayışıdır. Sanayileşme ve buna bağlı olarak kentleşmenin yol açtığı sefalet ve tehlikelere karşı işçileri korumak amacıyla ekonomik ve sosyal yaşamda alınan önlemler bütünüdür (Koray-Topçuoğlu, 1995: 3). Anlaşıldığı üzere, işçi ve işveren arasında oluşan sorunlar ve çatışmaları gidermek, işçilerin çalışma ve yaşam koşullarını iyileştirmek dar anlamda sosyal politikanın hedefleridir.

$\mathrm{Bu}$ anlamıla sosyal politika aslında insanlık tarihi kadar eskidir. Sanayi devriminden önce de insanlar arasında güçsüz, yaşlı, özürlü ve yardıma muhtaç olanlar bakılıp gözetiliyordu. Bu manada sosyal politika tüm zayıf ve güçsüzlerin korunmasının yanında sosyal refahın artmasını da kapsar. Sosyal sorun sağlık, eğitim, konut, çevre, yerleşim sorunları, personel sorunları ve demokratikleşmeyi de içine alacak şekilde geniş bir çerçevede ve kapsamda anlam ve içerik kazanmaktadır.

\section{Yerel Yönetimler}

Sosyal politikaların oluşturulması ve etkin bir şekilde uygulanması üzerine yapılan araştırmalarda yerel yönetimlerin merkezi yönetime göre daha etkin olduğu sonucuna ulaşılmıştır (Ersöz, 2006: 760). Sosyal politika başlığı altına toplanabilecek sosyal yardım, sosyal hizmet, eğitim, sağlık, kültür ve konut başlıklarında, mahalli sorunların tespit edilmesinde ve bu sorunların çözümlenmesinde belediyeler halka yakınlık derecesi oranında merkeze göre daha etkindirler. Ancak belediyelerin sosyal politikaları uygulamalarındaki etkinliği büyük oranda mali yapılarına ve merkezi yönetimin refah devleti yaklaşımına bağlıdır (Ersöz, 2006: 760).

Son 20 yılda yerel yönetimler bölgelerinin ekonomik gelişimlerinde kritik roller oynamışlardır (Mike-Imrie, 1999: 58). Ancak bu kritik ve önemli rolüne rağmen belediyeler tek başlarına uygulamaları ile özellikle 
sosyal sorunların başında gelen yoksulluğu düşüremezler (Torjman-Leviten, 2003: 21).

Türkiye gibi Sivil Toplum Kuruluşlarının gelişmediği, ara korunak mekanizmalarının etkisiz olduğu, devletin sosyo-ekonomik fonksiyonlarını yitirdiği ülkelerde yerel yönetimlerin sosyal devlet misyonunu üstlenmeleri kaçınılmaz bir durumdur (Akdoğan, 2002:). Ülkemizde sosyal politika kapsamına giren görev ve sorumluluklar 5393 sayılı Belediye Kanununun 14. maddesinin " $b$ " fikrasında sayılmış ve uygulama takdiri belediyelere bırakılmıştır (Ersöz, 2004: 23). Bu fikranın üçüncü paragrafında "Hizmetlerin yerine getirilmesinde öncelik sırası, belediyenin malî durumu ve hizmetin ivediliği dikkate alınarak belirlenir." cümlesi ile belediyelere kanunda belirtilen ve belirli bir sınırı olmayan sosyal politika uygulamalarında serbestlik tanınmıştır.

Bir ülkeyi, özellikle Türkiye ölçeğinde büyük bir ülkeyi tek bir merkezden yönetmek mümkün değildir. Kamu hizmetlerinin verimliliği ve etkinliğini artırmak için yerel yönetimlerin varlığı önemlidir. Yerel yönetimler belirli bir amaçlara ulaşmak, belirli ihtiyaçlara yanıt vermek için ortaya çıkmış birimlerdir (Keleş, 1994: 21).

Ülkemizde "İl özel idaresi”, "belediye" ve "köy” olmak üzere üç türlü yerel yönetim birimi vardır. Ancak ülkemizde belde veya beldeye ait hizmetler denildiğinde, il özel idarelerinden çok Belediyeler akla gelmektedir. Kente yönelik hizmetler belediyelerin varlık sebebidir (Toprak, 1988: 103). Biz de konumuzla ilişkili olan yerel yönetim birimini belediye olarak ele alacağız.

Yönetim sistemimiz içinde yaklaşık 150 yıllık bir geçmişi bulunan belediye de, il özel idaresi gibi, Osmanlı'dan Cumhuriyet'e intikal eden yönetim kurumlarındandır (Eryılmaz, 2002: 136). Cumhuriyet döneminde ilk olarak 1930 yılında çıkartılan 1580 sayılı Belediye Kanunu ile belediyeler düzenlenmiştir. Ancak bu konuda en son düzenleme 5393 sayılı Belediye Kanunu ile yapılmıştır. Bu kanuna göre nüfusu 5000'i aşan yerleşim merkezleri ile tüm il ve ilçe merkezlerinde belediye kurulmaktadır.

\section{Avrupa'da Belediyeciliğin Gelişim Süreci}

Sanayi devrimine kadar geçen sürede belediyecilik anlamında önemli bir gelişme yaşanmamıştır. Yerel yönetimler Sanayi devrimi öncesi 
Avrupa'da daha çok bağımsız şehir yönetimleri şeklinde ortaya çıkmıştır. Kent yönetimleri temel kentsel hizmetlerin yanısıra günümüzün üniter devletleri tarafından yerine getirilen önemli sosyal politika fonksiyonları üstlenmişlerdir. Su arzı, atık sistemi, yol sistemi gibi kentsel hizmetler ve kadın ve çocuk emeğinin denetimi, kamu sağlığı sistemlerinin oluşturulması, okullar, yoksullar ve yaşlılar için bakım imkanlarının geliştirilmesi gibi sosyal politika hizmetleri bu yönetimler tarafından karşılanmışlardır (Ersöz, 2007: 761).

18 yüzyıl sonunda gerçekleşen sanayi devrimi ile birlikte tarım toplumundan sanayi toplumuna geçilmesi kentlerin sanayi merkezi olarak ortaya çıkması ve buralara köylerden yoğun göç olması yeni bir dönemin başlangıcı olmuştur. Kentlerin nüfusları hızla artmış, bu yoğun nüfus çarpık kentleşme, hava kirliliği, alt yapı yetersizliği gibi sorunlarla karşılaşmışlardır. Bu sorunların çözümünde yeni arayış ve çabalar Avrupa belediyeciliğini derinden etkilemiş ve yerel yönetimlerin önemini artırmıştır (Aydınlanma1923, 2004). Endüstri devriminden İkinci dünya savaşına geçen periyotta yerel yönetimlerin sosyal politika alanındaki işlevi 20. yüzyılın başlarına kadar genelde yoksullara yardım ölçeğinde kalmıştır.

Belediyelerin önemi özellikle sosyal politika fonksiyonlarındaki rol ve etkinliği İkinci Dünya savaşından sonra refah devleti kavramı ile birlikte artmıştır. 1945-1975 döneminde refah devletleri gibi, birçok ülkede, yerel yönetimler de "altın çă̆" diye nitelendirilen bir dönemi yaşamışlardır (Ersöz, 2007: 1).

\section{Türkiye'de Belediyeciliğin Gelişim Süreci}

Selçuklularda birinci derecede belediye işleri kadıların yetkisinde idi. Osmanlılarda ise kuruluşundan 1850'li yıllara kadar bir belediye örgütlenmesi yoktu. Devletin görmesi gereken belediye hizmetleri vakıflar aracılığı ile görülüyordu. Bunlar: su işleri, temizlik işleri, aydınlatma işleri, parklar ve bahçeler, mezarlıklar, yol ve altyapı hizmetleri, halk sağlığını koruyucu çalışmalardır. Bu işler için halktan vergi toplanmıyordu. Ancak 19. yüzyılda sanayi devriminden sonra Osmanlı' da el sanatlarına dayanan geleneksel ekonominin çöküşü ile birlikte vakıfların 
gelirleri azalmış bu durum vakıf hizmetlerinin sağlıklı bir şekilde görülmesini engellemiştir (Aydınlanma1923, 2004).

Osmanlı döneminde İstanbul dışında diğer şehirlerde belediye kurulması 1870 'den sonra olmuştur. Vilayet yönetimini yeniden düzenleyen 1871 tarihli “İdare-i Umumiye-i Vilayet Nizamnamesi” aynı zamanda belediyelerin ilk yasal temeleni oluşturur. Şehir ve kasabalardaki belediye örgütünün yaygın bir şekilde kurulması 1877 yılında yürürlüğe giren "Vilayetler Belediye Kanunu" ile gerçekleşti. Bu yasa 1930 yılında kabul edilen 1580 sayılı Belediye Kanununa kadar yürürlükte kaldı (Eryılmaz, 2002: 178).

Cumhuriyet döneminde 1930 yılında 1580 sayılı belediye yasası çıkarılarak belediyelerin fonksiyonları düzenlenmiştir. Fransa'dan uyarlanarak yapılan bu yasa çıkarıldığı yılların sosyo-ekonomik şartları içinde yeterli, hatta ileri düzenlemeler içermekte idi. Yaklaşık 75 yıl yürürlükte kalan bu yasa belediyelere geniş bir faaliyet alanı tanımaktaydı (Ersöz, 2006: 761 ). Daha sonra 7 Aralık 2004 tarihinde çıkartılan 5272 no'lu yasa belediye kanunu olarak yürürlüğe girdi ancak Anayasa Mahkemesi bu yasayı 18 Ocak 2005 tarihinde iptal etti. İptal edilen bu yasanın yerine 13 Temmuz 2005 tarihinde 5393 sayılı yasa yürürlüğe girdi.

\section{Belediyecilik Ile Ilgili Yasal Düzenlemeler}

\section{Anayasa'da Yerel Yönetimler}

Yerel yönetimler, 1982 Anayasasında 2. bölümde "Yürütme" başlı̆̆1 altında, "İdarenin kuruluşu" kenar başlığında 127. maddede şöyle tarif edilmiştir: Mahallî idareler; il, belediye veya köy halkının mahallî müşterek ihtiyaçlarını karşılamak üzere kuruluş esasları kanunla belirtilen ve karar organları, gene kanunda gösterilen, seçmenler tarafından seçilerek oluşturulan kamu tüzel kişileridir. Mahallî idarelerin kuruluş ve görevleri ile yetkileri, yerinden yönetim ilkesine uygun olarak kanunla düzenlenir.

Anayasa' da da görüldüğü üzere belediyeler bulunduğu bölgenin yerel ihtiyaçlarını karşılamak üzere oluşturulmuş kamu tüzel kişileridir. Bu ihtiyaçları en yakından tanıyan halka en yakın yerel yönetimlerdir. 


\section{Sayılı Büyükşshir Belediye Kanunu'nda Sosyal Politika Görevleri}

Nüfusu 750 bini aşan illerde kanunla büyükşehir belediyesi kurulabilir. Ülkemizde 16 adet büyükşehir belediyesi bulunmaktadır. Büyükşehir belediyelerine yasa ile verilen bazı sosyal politika görev ve sorumlulukları mevcuttur. Bunlar yasanın 7. maddesinin (n) ve (v) fikralarında yer almaktadır. " $n$ " fıkrası büyükşehir belediyelerine gerektiğinde sağlık, eğitim ve kültür hizmetleri için bina ve tesisler yapmak, kamu kurum ve kuruluşlarına ait bu hizmetlerle ilgili bina ve tesislerin her türlü bakımını, onarımını yapmak ve gerekli malzeme desteği sağlamak şeklinde görevler verirken, " $\mathrm{v}$ " fıkrası: sağlık merkezleri, hastaneler, gezici sağlık üniteleri ile yetişkinler, yaşlılar, engelliler, kadınlar, gençler ve çocuklara yönelik her türlü sosyal ve kültürel hizmetleri yürütmek, geliştirmek ve bu amaçla sosyal tesisler kurmak, meslek ve beceri kazandırma kursları açmak, işletmek veya işlettirmek, bu hizmetleri yürütürken üniversiteler, yüksek okullar, meslek liseleri, kamu kuruluşları ve sivil toplum örgütleri ile işbirliği yapmak görevlerini vermiştir.

\section{Sayılı Belediye Kanunu'nda Belediyelerin Görevleri}

Belediyeler, belde halkının günlük ihtiyaçlarının karşılanmasında birinci derecede sorumlu kuruluşlar olarak kabul edildikleri için temel kentsel hizmetlerin ve altyapı tesisinde, sosyal ve hatta kültürel konulara kadar birçok alanda sorumluluklar üstlenmişlerdir (Aydın, 2008: 115)

3 Temmuz 2005 tarihinde kabul edilen 5393 no'lu belediye konusunda belediyelerin görevleri şu şekildedir :

MADDE 14. - Belediye, mahallî müşterek nitelikte olmak şartıyla;

a) İmar, su ve kanalizasyon, ulaşım gibi kentsel alt yapı; coğrafî ve kent bilgi sistemleri; çevre ve çevre sağlı̆̆ zabıta, itfaiye, acil yardım, kurtarma ve ambulans; şehir içi trafik; defin ve mezarlıklar; ağaçlandırma, park ve yeşil alanlar; konut; kültür ve sanat, turizm ve tanıtım, gençlik ve spor; sosyal hizmet ve yardım, nikâh, meslek ve beceri kazandırma; ekonomi ve ticaretin geliştirilmesi hizmetlerini yapar veya yaptırır. Büyükşehir belediyeleri ile nüfusu 50.000'i geçen belediyeler, kadınlar ve çocuklar için koruma evleri açar. 
b) Okul öncesi eğitim kurumları açabilir; Devlete ait her derecedeki okul binalarının inşaatı ile bakım ve onarımını yapabilir veya yaptırabilir, her türlü araç, gereç ve malzeme ihtiyaçlarını karşılayabilir; sağlıkla ilgili her türlü tesisi açabilir ve işletebilir; kültür ve tabiat varlıkları ile tarihî dokunun ve kent tarihi bakımından önem taşıyan mekânların ve işlevlerinin korunmasını sağlayabilir; bu amaçla bakım ve onarımını yapabilir, korunması mümkün olmayanları aslına uygun olarak yeniden inşa edebilir. Gerektiğinde, öğrencilere, amatör spor kulüplerine malzeme verir ve gerekli desteği sağlar, her türlü amatör spor karşılaşmaları düzenler, yurt içi ve yurt dışı müsabakalarda üstün başarı gösteren veya derece alan sporculara belediye meclisi kararıyla ödül verebilir. Gıda bankacılığı yapabilir.

Belediye hizmetleri, vatandaşlara en yakın yerlerde ve en uygun yöntemlerle sunulur. Hizmet sunumunda özürlü, yaşlı, düşkün ve dar gelirlilerin durumuna uygun yöntemler uygulanır. Belediyenin görev, sorumluluk ve yetki alanı belediye sınırların kapsar. Belediye meclisinin kararı ile mücavir alanlara da belediye hizmetleri götürülebilir. 14. maddenin a fıkrasında açıkça sosyal politikaların temeli sayılan sosyal hizmet ve yardım görevi zikredilmiş ve bu çerçevedeki hizmetler arasında nitelendirilebilecek olan kadın ve çocuklar için koruma evleri açma görevi verilmiştir (Aydın, 2008: 117). Büyükşehir belediyeleri ile nüfusu 50.000'i geçen belediyeler, kadınlar ve çocuklar için koruma evleri açacaklardır. Yine bu kapsamda belediyeler okullara, öğrencilere ve amatör spor kulüplerine destek olabileceklerdir. Yine aynı maddenin a fıkrasında yer alan önemli bir görev, belediyeler hemşerilerine meslek ve beceri kazandırmak amacıyla faaliyetlerde bulunmadır.

\section{Sosyal Politika Ve Belediye}

Sosyal politika gerek kavram gerek kapsam ve gerekse politikalarının belirlenmesi ve bu politikaları uygulayan kurumlar bakımından kesin sınırları çizilemeyen bir alandır. Sosyal politika tanımlarına bakıldığında çok çeşitli yaklaşımlarla karşılaşılır. Örneğin İngiltere'de sosyal politika sosyal refahı temin etmesi olarak ele alınırken, (Walsh- Stephens- Moore, 
2000: 2) başka bir tanımda devletin sosyal durum ve imkanlara müdahale biçimi olarak değerlendirilmektedir.

Gelişmiş ülkelerde devlet İkinci Dünya Savaşından sonra refah devleti olarak algılanmaya başlamış ve 1945 - 1975 dönemleri arasında yerel yönetimler bu konuda çalışmalar yapmışlardır. Bu dönemde kentlerin sosyal kalkınmasında yerel yönetimler önemli roller oynamışlardır (Aydın, 2008: 42). 1980'li yıllarda belediyelerin bu konudaki fonksiyonlarında daralma olsa da 1990'l1 yılların ikinci yarısında desantralizasyon etkisi ile yerel kalkınmadan istihdam sağlamaya, işsizlik ve yoksullukla mücadele etme konusuna kadar yerel yönetimler yeniden inisiyatif kullanmaya başlamışlardır (Kesgin, 2008: 102).

Tablo 1: Sosyal Politika Sağlayan Gruplar

\begin{tabular}{|c|c|c|c|}
\hline $\begin{array}{c}\text { Sosyal Ku- } \\
\text { rumlar }\end{array}$ & $\begin{array}{l}\text { Örgütlenme } \\
\text { Biçimleri }\end{array}$ & $\begin{array}{c}\text { Temel Fonksiyon- } \\
\text { ları }\end{array}$ & $\begin{array}{c}\text { Sosyal Refah Fonksiyon- } \\
\text { ları }\end{array}$ \\
\hline Sivil Kesim & Aileler & $\begin{array}{l}\text { Üreme, sosyalleşme, } \\
\text { koruma, dostluk, } \\
\text { manevi destek }\end{array}$ & $\begin{array}{l}\text { Bağımlı üyelerinin bakımı, } \\
\text { aile içi mali destek }\end{array}$ \\
\hline Din & Dini kurumlar & Ruhi gelişme & $\begin{array}{l}\text { Üyelerine refah, sağlık, } \\
\text { eğitim, sosyal hizmetler } \\
\text { sağlamak ve danışmanlık }\end{array}$ \\
\hline İşyeri & $\begin{array}{l}\text { İş organizasyon- } \\
\text { ları }\end{array}$ & İstihdam & İşçi ödenekleri \\
\hline $\begin{array}{l}\text { Piyasa(özel } \\
\text { sektör) }\end{array}$ & $\begin{array}{l}\text { Üreticiler(firma) } \\
\text { ve tüketiciler } \\
\text { (Hane halkı) }\end{array}$ & $\begin{array}{l}\text { Mal ve hizmetlerin } \\
\text { değişimi }\end{array}$ & $\begin{array}{l}\text { Mal ve hizmetlerin ticari } \\
\text { sosyal refahı }\end{array}$ \\
\hline $\begin{array}{l}\text { Gönüllü sektör } \\
\text { karşıllklı yardım }\end{array}$ & $\begin{array}{l}\text { Gönüllü ku- } \\
\text { ruluşlar, gruplar }\end{array}$ & $\begin{array}{l}\text { Karşılıklı yardım, in- } \\
\text { san sevgisi, yardım- } \\
\text { severlik }\end{array}$ & $\begin{array}{l}\text { Kendi kendine yardım, } \\
\text { gönüllülük, topluma } \\
\text { yönelik sosyal hizmetler }\end{array}$ \\
\hline Devlet & $\begin{array}{l}\text { Merkezi yöne- } \\
\text { timler, bölgesel ve } \\
\text { yerel yönetimler }\end{array}$ & $\begin{array}{l}\text { Toplumsal amaçlarla } \\
\text { kaynakların } \\
\text { yönlendirilmesi ve } \\
\text { dağıtılması }\end{array}$ & $\begin{array}{l}\text { Yoksulluğun önlenmesi, } \\
\text { ekonomik güvenlik, } \\
\text { sağllk, eğitim ve konut } \\
\text { hizmetleri }\end{array}$ \\
\hline
\end{tabular}

Kaynak H.Y.ERSÖZ; Sosyal Politika Perspektifinden Yerel Yön.;İstanbul, Filiz Kitabevi, 2004; s. 13

$\mathrm{Bu}$ anlamda, belediyeler bir kamu kurumu olarak, yerel dinamikleri dikkate alacak şekilde diğer aktörlerle koordineli olarak yerelde sosyal politikaları "esnek yürüten aktör" konumunda olmalıdır (Taşçı, 2017, 55). Yerel yönetim birimlerinden biri olan belediyelerin temel kentsel hiz- 
metlerin yanında sayabileceğimiz görevleri, fiziki mekanları düzenlemenin ötesinde, halkın yaşam kalitesini yükseltmek, kimsesiz, yoksul, özürlü, yaşlı, kadın ve çocukları gözetmek, yersiz yurtsuzlara iş bulmak ve korumaktır. Diğer bir ifade ile belediyeler bir anlamda "sosyal rehabilitasyon" işlevlerini de üstlenmiş durumdadırlar (Aytaç, 2010: 132). Bu rehabilitasyon çerçevesinde belediyeler bireyin sosyalleşmesinde sosyal eğitim işlevi de görebilirler (Es, 2007: 29). Diğer bir açıdan yerel sosyal politikalar, mahalli düzeyde, yöre sakinlerinin ve STK'ların beceri ve kaynaklarından yararlanılarak, sosyal hayatın ve gücünün, yerel ekonomik ve sosyal gelişmeyle desteklenmesini öngören politikalardır (Seyyar, 2008: 32).

Konut: 5393 sayılı yasanın 69. maddesinde belediyelere imarlı ve alt yapılı arsalar üretmek; konut, toplu konut yapmak, satmak, kiralamak ve bu amaçlarla arazi satın almak, kamulaştırma yapmak, bu arsaları trampa etmek, bu konuda ilgili diğer kamu kuruluşları ve bankalarla iş birliği yapmak ve gerektiğinde onlarla ortak projeler geliştirmek yetkisi tanınmıştır (Aydın, 2008: 144).

Ĕ̆itim ve Săğlk: Yerel yönetimler yerel halkın sosyal ihtiyaçlarını belirlemede ve bu ihtiyaçları karşılamada merkezi yönetime göre daha elverişli bir konumdadırlar (Pektaş, 2010, 11). Devlete ait her derecedeki okul binalarının inşaatı ile bakım ve onarımını yapabilme veya yaptırabilme ile her türlü araç gereç ve malzeme ihtiyaçlarını karşılayabilmeleri. Yine il sınırları içinde Büyükşehir belediyeleri, belediye ve mücavir alan sınırları içinde il belediyeleri ile nüfusu 10.000'i geçen belediyeler, meclis kararıyla; sağlık yatırımlarının ve eğitim kurumlarının su, termal su, kanalizasyon, doğal gaz, yol ve aydınlatma gibi alt yapı çalışmalarını faiz almaksızın on yıla kadar geri ödemeli veya ücretsiz olarak yapabileceklerdir. Ayrıca meslek ve beceri kazandırma kursları açma görevi bu kapsamda değerlendirilen görevler arasındadır.

Sağlık alanında ise belediyelere mahalli müşterek nitelikte olmak şartıyla, acil yardım, kurtarma ve ambulans hizmetlerini yerine getirme görevi ve sağlıkla ilgili her türlü tesisi açabilme işletebilme imkanı verilmiştir. 
Sosyal Yardım ve Sosyal Hizmetler: Belediyeler yerellik ilkesi ile hareket ettiklerinden, sakinlerin ihtiyaçlarını belirlemede merkezi otoriteden daha sağlıklı davranma imkanına sahip olmaktadırlar. Belediyeler, konut, eğitim, sağlık konusunda olduğu gibi, sosyal yardım ve hizmetlerin de ulaştırılmasında merkezi yönetime göre daha hızlı ve isabetli olabilmektedirler (Beki, 2009: 74). Belediyelerin sosyal nitelikli uygulamalarının merkezi yönetimin bu alandan uzaklaşmasıyla daha fazla arttığı görülmektedir. Görevlerin ve yetkilerin yerel yönetimlere devredilmesi süreci ile birlikte belediyeler yerel sosyal sorunlara karşı daha aktif politikalar üretmeye başlamışlardır. Söz konusu aktif politika araçlarından birisi de sosyal belediyeciliktir (Kesgin, 2008, 55). Sosyal politikalara ilişkin önemli yetki ve sorumluluklarla donatılan yerel kamu yöneticileri, bulundukları bölgenin sosyo-ekonomik sorunlarının tespitinde ve çözümünde, dezavantajlı sosyal grupların mağduriyetlerinin giderilmesinde etkin roller üstlenmektedirler (Pektaş, 2010: 11).

Ülkemizde belediyelerin en çok yerine getirdiği sosyal politikalar sosyal yardım ve sosyal hizmet alanındadır. Belediyeler 5393 no'lu yasada bu yardım ve hizmetlerin sağlanmasından sorumlu tutulmuşlardır. Yasada sosyal yardım ve hizmetler konularından bazılarına özellikle vurgu yapılmıştır. Bunlar; kadın ve çocuklar için koruma evleri açma, gıda bankacılığı, fakir öğrencilere destek (md14), dar gelirlilere ve afete maruz kalanlara arsa tahsisi yapma (md69/3), olarak sıralanabilir. Bizzat belediye başkanına verilen görev özürlülere yönelik hizmetleri yürütmek ve özürlüler merkezini oluşturmaktır. Bu düzenlemelere ek olarak belediyelerin gider kalemlerinden biri, dar gelirli, yoksul, muhtaç ve kimsesizler ile özürlülere yapılacak sosyal hizmet ve yardımlardır.

Belediyelerin mahalli alanlarda hizmet üretimlerinde ve bunlara erişimde, bunlara ulaşamayan "yoksun kesim" olarak ifade edebileceğimiz gruplara sosyal yardım ve hizmet sunması, hem anayasal ölçütlerde sosyal devlet olmanın bir gereği hem de fonksiyonları gereğidir. Sosyal yardım ve hizmet açılımında bir taraftan yoksun durumdaki gruplara destek sağlamak yer alırken, diğer taraftan sosyal hizmet yönüyle de mahalli alanlarda herkes tarafından ihtiyaç duyulan sosyal içerikli hizmetlerini kapsamaktadır (Negiz, 2011: 324).

Ülkemizde belediyeler sosyal yardım kapsamında en fazla gida ve giyecek yardımı yapmakta, nakit yardımında bulunmaktadır (Aydın, 
2008: 152). Belediyelerin büyük bir çoğunluğu sosyal hizmetler ile ilgili çalışmalarında birinci aktör olarak görev almaktan çekinirken, sosyal yardımlarda ise önde olmayı tercih etmektedir (Kerman, 2009: 134). Bununla birlikte, büyükşehir ve büyükşehirlerdeki ilçe belediyeleri huzurevleri ve gündüz bakım evleri gibi müesseseler kurarak hem kurumsallaşmada hem de hizmet anlamında sosyal hizmet uygulamalarını hayata geçirmektedirler. Sosyal belediyecilik uygulamaları içinde yer alan sosyal hizmet faaliyetleri genel olarak Sosyal Hizmetler Genel Müdürlügü̈nce yerine getirilmektedir. Ancak, genelde bu birim faaliyetlerini yerine getirirken sunduğu hizmetlerin, istisnaları olsa da çağdaş bir sosyal hizmet sistemini yansıttı̆ını söylemek güçtür. Ayrıca sosyal hizmetler, Sosyal Yardımlaşma ve Dayanışma Fonu, belediyeler ve sivil toplum örgütlerinin işbirliği içerisinde de yerine getirilmektedir. Sosyal belediyecilik anlayışı çerçevesinde belediye yönetimi, çocuklara, gençlere, kadınlara, yaşlılara, engellilere ve risk gruplarına yönelik çeşitli sosyal hizmetler sunmaktadır. Ayrıca belediye yönetimi yaygın eğitim organizasyonları ve kriz döneminde sosyal hizmetlerde bulunabilmektedir. Belediyeler belirtilen dezavantajlı gruplara ve durumlara aşağıdaki sosyal hizmetleri sunmaktadır (Çelik, 2014: 7)

- Çocuklar: Kreş ve çocuk yuvaları, kimsesiz çocuklar için yuvalar ve çocuk kulüpleri kurmak.

- Kadınlar: Ana-çocuk sağlığı merkezleri, kadın sığınma evleri ve el sanatları değerlendirme merkezleri açmak.

- Engelliler: Engelliler için temel eğitim okulları, beceri kursları açmak, spor ve iletişim olanakları sağlamak.

- Yaşlilar: Güçsüzler yurdu ve huzurevleri açmak. Gençler: Gençlik merkezleri, spor tesisleri, danışma ve psikolojik danışma merkezleri açmak ve meslek edindirme kursları başlatmak.

- Risk grupları: Sokak çocukları, tinerci çocuklar, istismara uğramış çocukların aralarında bulunduğu grup için hukuki ve psikolojik yardım büroları kurmak.

- Yaygın eğitim organizasyonları: Okuma-yazma, çocuk bakımı ve eğitimi, çıraklık eğitimi ve beceri kazandırma eğitimleri vermek.

- Kriz dönemi hizmetleri: Savaş, terör ve doğal afet gibi durumlarda, barınma, beslenme ve temizlik hizmetleri sunmak. 
Belediyelerin sosyal yardımları ise bütçelerine ve yerel halkın ekonomik ve sosyal durumlarına göre değişim göstermektedir. Bu anlamda yapılan sosyal yardımlar, ayni ve nakdi olmaktadır. Nakdi yardımlara ilave olarak, gida yardımı, yakacak yardımı, 1. ve 2. el giyecek yardımı, eşya yardımı, sağlık hizmetleri yardımı, engelli ihtiyaçları yardımları belediyelerin belli başlı sosyal yardımlarından sayılabilir (Negiz, 2011: 333).

\section{Araştırma Yöntem ve Bulguları}

\section{Araştırmanın Yöntemi}

Pendik belediyesinin yaptığı yardımlar üzerine bir çalışma yapılmıştır. Pendik belediyesinden gıda veya maddi yardım alan vatandaşların demografik bilgileri, aldıkları yardım miktarı, sıklığı, kalitesi, yardımı ulaştıran memurun tutum ve davranışları ve aldığı bu sosyal yardımdan memnuniyeti üzerine bir anket hazırlanmıştır. Anket tercih edilmesinin başlıca nedeni, diğer veri toplama tekniklerine göre hem zaman hem maliyet açısından uygun olmasındır. Ayrıca anket yöntemi ile elde edilen verilerin sayısallaştırılarak nicel analiz yapılmasında kolaylık sağlamasından dolayı anket yardımıyla veri toplama tekniğinden yararlanılmıştır. Hazırlanan bu anket Pendik belediyesinden yardım alan vatandaşlara kolayda örnekleme metodu ile uygulanmıştır Kolayda örnekleme yöntemi sayesinde veriye hızlı bir şekilde ulaşabilme imkânı sağlamasından dolayı tercih edilmiştir (Bülbül \& Demirer, 2008).

Pendik belediyesinin resmi sitesinde yer alan nüfus sayısina bakıldığında Pendik nüfusu 663569 kişidir. Bu sayı ile İstanbul'un en büyük beşinci ilçesidir. Örneklem büyüklüğünün tespiti için,

$$
n=\frac{N \cdot s^{2} t_{\alpha, s d}^{2}}{(N-1) d^{2}}
$$

formülünden yararlanılmıştır (Özdamar, 2003). Bu formüle göre, Pendik belediyesi üzerinde yapılan çalı̧̧ma için \%90 güven düzeyinde 96 gözlem yeterlidir. Çalışma 200 kişi üzerinde yapıldığından, örneklemin temsil yeteneği yeterli görülmüştür. 
Anket ile elde edilen sonuçlar üzerinden demografik bilgiler analiz edilmiştir. Elde edilen sonuçlara bakıldığından eğitim düzeyi ile yardım talebi arasında ters orantılı bir ilişki olduğu görülmüştür. Kadınların yardım talebinde daha fazla bulunduğu gözlenmiştir.

Anket sorularının geçerliliği test edilmiştir. Bunun için SPSS programındaki Cronbach's Alpha değerinden yararlanılmıştır. Ayrıca anket verilerinin normallik dağılımı incelemek için basıklık ve çarpıkları her bir soru için ayrı ayrı incelenmiştir. Uygun olmayan değişkenler analizden çıkarılmış, normal dağılıma uygun olan değerler üzerinden analizlere devam edilmiştir. Normal dağılıma uygun olan değişkenler üzerinden faktör analizi uygulanmıştır. Faktör analizi ile tek bir faktör elde edilmiştir. Faktör analizi ile birbiriyle ilişkili çok değişkenin daha az değişken haline getirmek için kullanılan bir yöntemdir (Doğan \& Başokçu, 2010).

Faktör analizi ile elde edilen faktör ANOVA tablosu ile vatandaşların memnuniyetleri ile ilişkisinin olup olmadığına bakılmıştır. Varyans analizi (Analysis of Variance: ANOVA), ikiden fazla grubun ayn ortalamaya sahip olup olmadıklarını sınanmasında kullanılır. Elde edilen faktör ile vatandaşların memnuniyetleri arasında yapılan varyans analizinde, nakdi faktörün memnuniyete ortalamalarının farklı olduğu, dolayısıyla etkili olduğu sonucu çıkarılmıştır. ANOVA testinde her bir ana kütlenin normal dağılıma sahip olduğu ve varyanslarının da eşit olduğu varsayımı yapilmaktadır (Armutlulu, 2008).

\section{Araştırmanın Analizleri}

Anket yapılan 200 kişiye ait demografik bilgilerin temel istatistik verileri Tablo 2'de verilmiştir. Eksik veri tespit edilmemiştir. Ankete katıların ve yardım alanların \%40,5'i 31-40 yaş aralığındadır. Belediye tarafından yardım edilenlerin \%79'u kadın olup, kadınların yardıma daha ihtiyaç duydukları ve talep ettikleri söylenebilir. Yardım başvurusunda bulunanların \%66'sı evli olup, bekâr, dul ve boşanmışların toplam oranı ise ancak \%34'tür. Yardım alanların eğitim seviyelerine bakıldığında 200 kişiden 120 'sinin ilkokulu mezunu olduğu, eğitim seviyesinin düşük olduğu kişilerin ekonomik olarak destek almak zorunda kaldığı söylenebilir. Bu değerlere bakıldığında, artan eğitim seviyesi ile birlikte kurumlardan gıda ve maddi yardım talebinde bulunma oranlarında ciddi bir düşüş 
yaşandığ1 görülmektedir. Verilere göre eğitim seviyesi düştükçe yardım talebinde bulunma oranı da artmıştır. Buna göre ilkokul mezunu 120, ortaokul mezunu 27, lise mezunu 7, lisans mezunu 1 kişi yardım talebinde bulunarak almıştır. Buradan eğitim seviyesi ile yardım talebinde bulunma arasında bir ters orantı olduğu söylenebilir. Özel durumdan dolayı çalışamayan kişilerin kurumdan yardım aldıkları görülmüştür. Ayrıca yardım talebinde bulunan kişilerin evinin mülkiyet durumu incelenmiştir. İncelendiğinde \%72'sinin kiracı olduğu saptanmıştır.

\section{Tablo 2: Demografik Bilgilerin Temel İstatistikleri}

\begin{tabular}{|c|c|c|c|c|c|c|c|c|c|}
\hline \multicolumn{10}{|c|}{ Temel İstatistikler } \\
\hline & YaşınızC & insiyetir & $\begin{array}{l}\text { Medeni } \\
\text { zDuru- } \\
\text { munuz }\end{array}$ & $\begin{array}{l}\text { Öğrenim } \\
\text { Duru- } \\
\text { munuz }\end{array}$ & $\begin{array}{l}\text { Hanedeki } \\
\text { Kişi Sayısı }\end{array}$ & $\begin{array}{l}\text { Kişinin } \\
\text { İş Du- } \\
\text { rumu }\end{array}$ & $\begin{array}{l}\text { Hanede } \\
\text {-Çalışan } \\
\text { Savis1 }\end{array}$ & $\begin{array}{l}\text { Hanenin } \\
\text { Aylik Ge } \\
\text { liri }\end{array}$ & $\begin{array}{l}\text { Evin } \\
\text { e-Mülki- } \\
\text { yeti }\end{array}$ \\
\hline Geçerli & 200 & 200 & 200 & 200 & 200 & 200 & 200 & 200 & 200 \\
\hline Eksik Veri & 0 & 0 & 0 & 0 & 0 & 0 & 0 & 0 & 0 \\
\hline Ortalama & 3,4900 & 1,2100 & 1,8100 & 2,0000 & 2,6800 & 3,1700 & 1,7000 & 3,1500 & 2,8050 \\
\hline Medyan & 3,0000 & 1,0000 & 1,0000 & 2,0000 & 3,0000 & 4,0000 & 2,0000 & 3,0000 & 3,0000 \\
\hline Mod & 3,00 & 1,00 & 1,00 & 2,00 & 3,00 & 4,00 & 2,00 & 4,00 & 3,00 \\
\hline Std. Sapma & 1,09815 & , 40833 & 1,20046 & ,76349 & 86099 & 1,11233 & 61799 & 1,35895 & ,80637 \\
\hline Çarpıklık & 474 & 1,435 & ,971 & 1,163 &,- 142 &,- 961 & 426 &,- 081 & $-1,199$ \\
\hline $\begin{array}{l}\text { Çarpıklığın } \\
\text { Standart } \\
\text { Hatası } \\
\end{array}$ & 172 & 172 & 172 & 172 & 172 & 172 & 172 & 172 & , 172 \\
\hline Basıklık &,- 181 & 059 &,- 824 & 3,661 &,- 629 &,- 602 & 047 &,- 515 & 1,053 \\
\hline $\begin{array}{l}\text { Basıklığın } \\
\text { Standart } \\
\text { Hatası }\end{array}$ & ,342 & ,342 & ,342 & ,342 & ,342 & ,342 & ,342 & ,342 & ,342 \\
\hline Minimum & 1,00 & 1,00 & 1,00 & 1,00 & 1,00 & 1,00 & 1,00 & 1,00 & 1,00 \\
\hline Maksimum & 6,00 & 2,00 & 4,00 & 6,00 & 4,00 & 4,00 & 4,00 & 6,00 & 4,00 \\
\hline Toplam & 698,00 & 242,00 & 362,00 & 400,00 & 536,00 & 634,00 & 340,00 & 630,00 & 561,00 \\
\hline
\end{tabular}

Kolayda örnekleme ile 200 kişi üzerinde yapılan anketin Cronbach's Alpha değeri 0,717 olarak hesaplanmıştır. Çalışmanın analizleri SPSS ile yapılmıştır. Cronbach's alpha değeri 0,60' dan büyük olması durumunda yapılan çalışma orta düzeyde güvenilirdir. Bu değerin 0,80 ' den yüksek olması durumunda ise ölçek yüksek derecede güvenilir kabul edilir. Tablo 3'deki bu değer kabul edilebilir düzeyde olduğu görülmüştür (Özdamar, 2004). 
Tablo 3: Güvenilirlik (Cronbach's Alpha) Değeri

Güvenilirlik İstatistikleri

Cronbach's AlphaDeğişken Sayısı

$0,717 \quad 4$

Tablo 4: Anket Sorularını Tanımlayıcı Ístatistikleri

\begin{tabular}{|c|c|c|c|c|c|c|c|c|c|}
\hline \multicolumn{10}{|c|}{ Tanımlayıcı İstatistikler } \\
\hline & 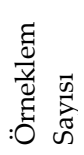 & 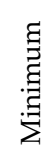 & 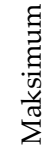 & $\begin{array}{l}\stackrel{\pi}{\Xi} \\
\frac{\pi}{\pi} \\
\stackrel{J}{0}\end{array}$ & 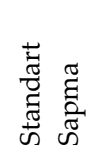 & & ư & & 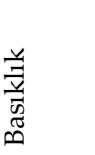 \\
\hline & 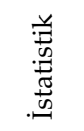 & 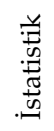 & 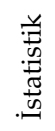 & 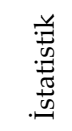 & 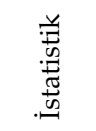 & 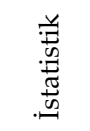 & 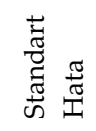 & 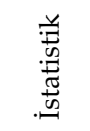 & 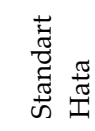 \\
\hline $\begin{array}{l}\text { Belediyeden kaç } \\
\text { yıldır yardım } \\
\text { alıyorsunuz? }\end{array}$ & 200 & 0 & 2 & 1,11 & 0,904 & $-0,209$ & 0,172 & $-1,753$ & 0,342 \\
\hline $\begin{array}{l}\text { Bir yıl içerisinde } \\
\text { belediyeden kaç } \\
\text { defa nakdi yardım } \\
\text { aldınız? }\end{array}$ & 200 & 0 & 2 & 0,79 & 0,917 & 0,430 & 0,172 & $-1,680$ & 0,342 \\
\hline $\begin{array}{l}\text { Bir sefer aldığınız } \\
\text { nakdi yardım } \\
\text { miktarı ne ka- } \\
\text { dardır? }\end{array}$ & 200 & 0 & 2 & 0,71 & 0,844 & 0,604 & 0,172 & $-1,329$ & 0,342 \\
\hline $\begin{array}{l}\text { Belediye dışında } \\
\text { başka }\end{array}$ & 200 & 0 & 2 & 0,49 & 0,672 & 1,038 & 0,172 &,- 134 & 0,342 \\
\hline
\end{tabular}

Verilerin temel tanımlayıcı istatistikleri Tablo 4 de verilmiştir. Çalışmaya konu olan dört değişken 3'lü likert ölçeği kullanılmıştır. Orta büyüklükteki örneklemler için $(50<\mathrm{n}<300)$, basıklık ve çarpıklık katsayılarının 3,29'dan düşük olması durumunda \%95 güven aralığında normal dağılıma uygundur (Kim, 2013\&Mardia, 1974). Çalışmadaki Yıl, Sıklık, TL ve Kuruluş değişkenlerin basıklık ve çarpıklık katsayıları 3,29' den küçük olmasından dolayı değişkenler normal dağılıma uygudur. Yapılacak olan faktör analizinin bir varsayımı da değişkenlerin normal dağılıma uygun olmasıdır (Doğan \& Başokçu, 2010). 
Analize tabi olan değişkenlere boyut indirgemek ve bir üst boyut değişkenin araştırılması için faktör analizi uygulanmıştır. Faktör analizi, birbiriyle ilişkili birden fazla değişkenin daha az ve birbirinden bağımsız değişkenler haline getirmek için kullanılan bir yöntem dir (Kalaycı, 2006). Faktör analizi, oran ölçekli değerlerde iyi, aralık ölçekli değişkenler ise kısmen iyi sonuçlar üretmektedir. Sıralı ölçekli analizlerde Likert, Thurstone veya Goodman ölçekler kullanılmış olması durumunda faktör analizi iyi sonuç verecektir (Özdamar, 2004). Faktör analizi ile elde edilecek faktörler hakkında önceden bilenen bir literatür olmadığından dolayı çalışmanın uygulama kısmında açılayıcı faktör analizinden yararlanılarak analiz yapılmıştır. Açıklayıcı faktör analizinde, faktör analizi sonucunda elde edilecek faktörler hakkında daha önceden bir bilgi olmaması durumunda kullanılan bir faktör analizi çeşididir. Bu analizde oluşacak olan faktörlerin belirlenmesi aşamasında çalışmaya konu olan değişkenlerin arasındaki genellikle korelasyondan yararlanılır (Sharma, 1976). Sonuçlarına bakıldığında Tablo değerlerine göre yapılan faktör analizinin anlamlı olduğu görülmüştür. KMO ve Bartlett's testine göre faktör analizinin yapılıp yapılamamasına bakılır. KMO değerinin 0,50 'den yüksek olması yapılan faktör analizinin uygun olduğunu göstermektedir (Kaiser, 1974). Çalışmamızın KMO değeri 0,589 olarak hesaplanmıştır. Ayrıca Bartlett's Testine göre, değişkenlerin korelasyon matrisi birim matrisden farklıdır. Bartlett's testinin anlamlılık değerine bakılarak değişkenlerin arasında anlamlı bir sonuç olduğu söylenebilmektedir (Kalayc1, 2006).

\section{Tablo 5: Anti-İmage Matrisi}

\section{Anti-image Matrisi}

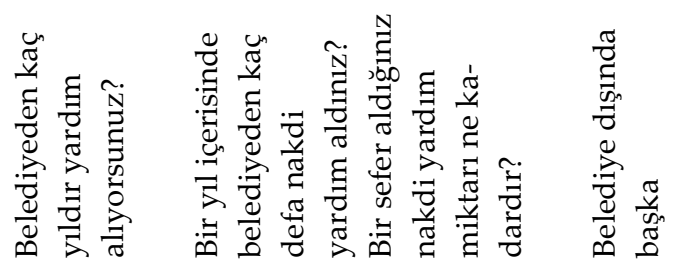

\begin{tabular}{lllll}
\hline \multirow{2}{*}{$\begin{array}{l}\text { B Belediyeden kaç yıldır } \\
\text { yardım alıyorsunuz? }\end{array}$} & $0,85 \mathrm{a}$ & $-0,08$ & $-0,02$ & $-0,17$ \\
\hline
\end{tabular}




\begin{tabular}{lllll}
\hline $\begin{array}{l}\text { Bir yıl içerisinde } \\
\text { belediyeden kaç defa } \\
\text { nakdi yardım aldınız? }\end{array}$ & $-0,08$ & $0,55 a$ & $-0,88$ & $-0,19$ \\
\hline $\begin{array}{l}\text { Bir sefer aldığınız nakdi } \\
\text { yardım miktarı ne ka- } \\
\text { dardır? }\end{array}$ & $-0,02$ & $-0,88$ & $0,55 a$ & 0,04 \\
\hline Belediye dışında başka & $-0,17$ & $-0,19$ & 0,04 & $0,81 \mathrm{a}$ \\
\hline
\end{tabular}

a. MSA

Anti-image matrisindeki değerlere bakıldığındaki, köşegen değerlerinin 0,50'nin üstünde olduğu görülmektedir. Anti-image matrisinin köşegen elemanlarının değerleri 0,50'den büyük olması halinde faktör analizinin anlamlı olduğu söylenebilmektedir.

Tablo 6: Faktör Analizi Toplam Varyans Tablosu

\begin{tabular}{lllllll}
\hline \multirow{2}{*}{ Birleşenler } & \multicolumn{2}{l}{ Başlangıç Öz Değerleri } & \multicolumn{3}{c}{ Faktör Yüklerinin Kareler Toplamı } \\
\cline { 2 - 7 } & $\begin{array}{l}\text { Toplam } \\
\text { Yäyansin } \\
\text { Yüzdesi }\end{array}$ & Kümülatif \% & Toplam & $\begin{array}{l}\text { Varyansın } \\
\text { Yüzdesi }\end{array}$ & $\begin{array}{l}\text { Kümülatif } \\
\%\end{array}$ \\
\hline 1 & 2,24 & 56,04 & 56,04 & 2,24 & 56,04 & 56,04 \\
\hline 3 & 0,91 & 22,76 & 78,80 & & & \\
\hline 4 & 0,75 & 18,61 & 97,41 & & & \\
\hline
\end{tabular}

Metot: Temel Birleşenler Analizi

Açıklanan toplam varyans tablosu incelendiğinde tek bir faktörün oluştuğu görülmektedir. Açıklayıcı faktör analizinde öz değer yükü 1 ve üstü olarak alınmıştır. Dört değişken ile yapılan faktör analizinde tek bir faktör oluşmaktadır. Oluşan bu faktör toplam varyansı açıklama yüzdesi $\% 56,04$ 'tur.

Tablo 7: Faktör Analizi

\begin{tabular}{lllll}
\hline & $\begin{array}{l}\text { Faktör } \\
\text { Ağırlıkları }\end{array}$ & $\begin{array}{l}\text { Faktör } \\
\text { Açıklayıcılı̆̆ı } \\
(\%)\end{array}$ & $\begin{array}{l}\text { Güvenilirlik } \\
\text { (Cronbach's } \\
\text { pha) }\end{array}$ & Al- KMO \\
\hline Faktör 1 & & 56,04 & 0,717 & 0,589 \\
\hline $\begin{array}{l}\text { Belediyeden kaç yıldır } \\
\text { yardım alıyorsunuz? }\end{array}$ & 0,49 & & & \\
\hline
\end{tabular}




\begin{tabular}{ll}
\hline $\begin{array}{l}\text { Bir yıl içerisinde } \\
\text { belediyeden kaç defa } \\
\text { nakdi yardım aldınız? }\end{array}$ & 0,92 \\
\hline $\begin{array}{l}\text { Bir sefer aldığınız nakdi } \\
\text { yardım miktarı ne ka- } \\
\text { dardır? }\end{array}$ & 0,90 \\
\hline Belediye dışında başka & 0,58 \\
\hline
\end{tabular}

Oluşan tek faktöre ait değişkenlerin yükleri tablo 7 de verilmiştir. Tek bir faktör oluştuğundan dolayı rotasyon (döndürme) yapılamamıştır. Faktör matrisi ile faktörlerin hangi değişkenler ile ilişkili olduğ belirlenir. Tabloda görüldüğü üzere değişkenlerin, oluşan faktöre ait yükleri 0,30'un üzerindedir.

Sosyal yardım alanların aldıkları hizmetten memnun kalıp kalmamalarına bakılarak, oluşturulan faktör analiz edilmiştir. Anova tablosundaki anlamlılık 0,006 olarak hesaplanmıştır. Yardım alanların memnuniyet düzeyleri bu faktöre göre anlamlı farklılık gösterir.

Tablo 8: ANOVA Tablosu

ANOVA

\begin{tabular}{|c|c|c|c|c|c|}
\hline \multicolumn{6}{|l|}{ Memnuniyet } \\
\hline & Kareler Toplamı & $\begin{array}{l}\text { Serbestlik } \\
\text { recesi }\end{array}$ & $\begin{array}{l}\text { De-Kareler } \\
\text { Ortalaması }\end{array}$ & $\mathrm{F}$ & $\begin{array}{l}\text { Anlam- } \\
\text { lilik }\end{array}$ \\
\hline Gruplar Arası & 7,07 & 33 & 0,21 & 1,86 & 0,006 \\
\hline Grup İçi & 19,12 & 166 & 0,12 & & \\
\hline Toplam & 26,20 & 199 & & & \\
\hline
\end{tabular}

\section{Araştırmanın Bulguları}

İstanbul'un en büyük beş ilçesinden biri olan Pendik üzerinde yapılan çalışmada, belediyenin yapmış olduğu yardımlar karşılığında vatandaşın memnuniyeti ölçülmeye çalışılmıştır. Analizler sonucundan vatandaşların nakdi yardımlar ile memnuniyetlerinin ilişkili olduğu tespit edilmiştir. Faktör analizi ile elde edilen nakdi yardım boyutu ve vatandaşın memnuniyeti arasındaki ilişki ANOVA analizi ile bakılmıştır. Nakdi yardımın süresi, sıklığı, miktarı ve belediye dışından alımı, yardımın nakdi boyutunu (faktörünü) oluşturmaktadır. 
Belediyelerin yapmış oldukları nakdi yardımın, vatandaşların memnuniyetini etkilediği tespit edilmiştir. Vatandaşlar açısından belediyenin yaptığı nakdi yardımın önemli olduğu sonucu çıkarılmış olup, belediyelerin yapacakları yardımları nakdi olarak hem sürekliliği hem sıklığı hem de miktarı göz önünde bulundurarak yapıyor olması geri bildirimin olumlu olacağı söylenebilir.

\section{Sonuç}

Dünya'da giderek artan yerelleşme politikaları neticesinde, ülkeler yasal ve kurumsal altyapılarını yerinden yönetimi güçlendirecek şekilde düzenlemeye çalışmaktadırlar. Merkezi idarenin hantallaşması ve hizmetlerin zayıflaması ve maliyetlerinin artması da yerelleşme ihtiyacını artırmıştır. Bu süreçte, sosyal politikalar benzer şekilde değişimden etkilenmiş, hem dünyada hem de Türkiye'de mahalli idarelerin sosyal politikaları desteklemelerini sağlayacak politikalar üretilmiştir. Bu anlamda, Türkiye'de merkezi idare tarafından, belediyelerin sosyal alana yönelmelerini sağlayacak yasal ve kurumsal düzenlemeler yapılmıştır.

Çalışmada İstanbul'un önemli ilçelerinden olan Pendik belediyesinin sosyal yardımları yapılan bir saha çalışması ile analiz edilmiştir. Özellikle sosyal yardımları kimlerin aldığı, demografik özelliklerinin ne olduğu ve aldıkları yardımlardan memnun olup olmadıkları değerlendirilmiştir. Ankete katıların ve yardım alanların \%40,5'i 31-40 yaş aralığındadır. Belediye tarafından yardım edilenlerin \%79 'u kadın olup, kadınların yardıma daha çok ihtiyaç duydukları ve talep ettikleri söylenebilir. Yardım başvurusunda bulunanların \%66'sı evli olup, bekâr, dul ve boşanmışların toplam oranı ise ancak \%34'tür. Yardım alanların eğitim seviyelerine bakıldığında 200 kişiden 120'sinin ilkokulu mezunu olduğu, eğitim seviyesinin düşük olduğu kişilerin ekonomik olarak destek almak zorunda kaldığı söylenebilir.

Verilere göre eğitim seviyesi düştükçe yardım talebinde bulunma oranı da artmıştır. İlkokul mezunu 120, ortaokul mezunu 27, lise mezunu 7, lisans mezunu 1 kişi yardım talebinde bulunarak almıştır. Buradan eğitim seviyesi ile yardım talebinde bulunma arasında bir ters orantı olduğu söylenebilir. Özel durumdan dolayı çalışamayan kişilerin kurumdan yardım aldıkları görülmüştür. Ayrıca yardım talebinde bulunan 
kişilerin evinin mülkiyet durumu incelenmiştir. İncelendiğinde \%72'sinin kiracı olduğu saptanmıştır.

Pendik Belediyesi'nden sosyal yardım alanların "belediyenin vermiş olduğu nakit ve gıda yardımlarından genel anlamda memnun musunuz?" sorusuna \%84,5 oranında "evet memnunum" cevabı verdiği görülmüştür. Ayrıca yardım alanların \%59'u hane halkı sayısı 4 ve üzeri olanlardan oluşmaktadır. Bir diğer ifadeyle, belediyenin sosyal yardımlarından faydalananlarının çoğunluğunun hane halkı sayısının fazla olması, muhtemelen muhtaçlık seviyelerinin de fazla olduğu anlamına gelmektedir.

Çalışmanın faktör analizinden çıkan "nakdi yardım" boyutun, belediyelerden yardım alan vatandaşların memnuniyetleri üzerinde etkili olduğu tespit edilmiştir. Nakdi yardımın süresi, sıklığı, miktarı ve belediye dışından alımı, yardımın nakdi boyutunu (faktörünü) oluşturmaktadır. Oluşan bu nakdi boyut memnuniyetleri üzerinde istatistiksel olarak anlamlı bir etki oluşturduğu ortaya konmuştur. Vatandaşların memnuniyetleri ile demografik bilgilere bakıldığında, istatistiksel anlamda yaş, cinsiyet, medeni durum, öğrenim durumu, hane halkı sayısı, iş, gelir ve mülkiyet durumlarına göre gruplar arasında anlamlı fark bulunamamıştır.

\section{Kaynakça}

Akdoğan, Y. (2002). "Ulusal soruna yerel çözüm: Sosyal Belediyecilik", Eminönü Bülteni, Şubat sayısı. İstanbul, 2002, www.yerelsiyaset.com, 15.02.2010

Alper, Y. (2004). Sosyal Güvenlik Kavramsal, Kurumsal Yapı, Kapsam, Finansman ve İvazlar; Uludağ Üni. İİBF ÇEKO Sosyal Güvenlik Teorisi Ders Notlarl; Bursa.

Andrew, C. \& Goldsmith, M. (1998).“From Local Government to Local Governance: And Beyond", International Political Scence Review,19 (2), 101-117.

Armutlulu, İ. H. (2008). İşletmelerde Uygulamalı İstatistik, İstanbul: Alfa Basım Yayım Dağıtım Ltd. Şti.

Aydın, M. (2008). Sosyal Politika ve Yerel Yönetimler, İstanbul: Yedirenk. 
Aytaç, S. (2010) ; “İstihdam ve Koruma Alanı Yaratmak Üzere Özürlüler İçin Sosyal Yaşam Merkezi Projesi", çevrimiçi, http://iibf.kocaeli.edu.tr/ceko/armaganlar/turanyazgan/04.pdf 15.02.2010

Beki, A, (2009). Türkiye'de Sosyal Belediyecilik, İstanbul: Sena Yayıncılık Bülbül, H., \& Demirer, Ö. (2008). Hizmet Kalitesi Ölçüm Modelleri Servqual ve Serperf'in Karşılaştırmalı Analizi, Selçuk Üniversitesi Sosyal Bilimler Enstitüsü Dergisi, 181-192

Çelik, A., (2014). "Sosyal Belediyecilik Anlayışı: Şanlıurfa Büyükşehir Belediyesi Örneği", Gazi Üniversitesi İktisadi ve İdari Bilimler Fakültesi Dergisi, 16(1), 1-20.

Doğan, N., \& Başokçu, T. O. (2010). "İstatistik Tutum Ölçeği İçin Uygulanan Faktör Analizi ve Aşamalı Kümeleme Analizi Sonuçlarının Karşılaştırılması", Eğitimde ve Psikolojide Ölçme ve Değerlendirme Dergisi, 65-71.

Ersöz, Halis Y. (2004). Sosyal Politika Perspektifinden Yerel Yönetimler (İngiltere, İsveç ve Türkiye Örneği), Filiz Kitabevi, İstanbul,

Ersöz, Halis Y. (2006). “Sosyal Politika-Refah Devleti- Yerel Yönetimler İlişkisi”, İ.Ü. İktisat Fakültesi Mecmuası Prof. Dr. Toker Dereli'ye Armağan Kitabı (Yayına kabul edilmiş çalışma), Cilt 55, Sayı 1, İstanbul, İ.Ü.Yayınları, s. 760

Ersöz, Halis Y. (2005). “5272 Sayılı Yasa Öncesinde Türkiye' de Belediyelerin Sosyal Politika Alanındaki Deneyimleri"; Sosyal Siyaset Konferansları, (Prof. Dr. Nevzat Yalçıntaş'a Armağan Özel Sayısı), Sayı: 50. İktisat Fakültesi Yayını. (Yayına kabul edilmiş çalışma), İstanbul, İ.Ü.Yayını.

Eryılmaz, B. (2002). Kamu Yönetimi, Erkam Matbaası, İstanbul

Es, M. (2007). “Kentsel Yoksulluğun Azaltılmasında Sosyal Belediyeciliğin Rolü"; Kent Üzerine Düşünceler; Okutan Yayıncllık; 1. baskı; İstanbul; 2007; s. 19-35

Güven, S. (1995). Sosyal Politikanın Temelleri, Ezgi Kitabevi, Bursa

Kaiser, H. F. (1974, Mart), "An Index Of Factorial Simplicity", Psychometrika, s. 31-36.

Kalaycı, Ş. (2006). SPSS Uygulamalı Çok Değişkenli İstatistik Teknikleri. Asil Yayınevi.

Keleş, R. (1994). Yerinden Yönetim ve Siyaset, Cem yayınları, İstanbul 
Kerman, U. Eda Çiçek, "Belediyelerin Sosyal Hizmet ve Yardımlarından Faydalanan Bireylerin Hizmetlere Yönelik Algıları: Isparta Örneği", Süleyman Demirel Üniversitesi Sosyal Bilimler Enstitüsü Dergisi, Y11: 2009/1, Say1: 9.

Kesgin, B. (2008). "Yoksulluğa Yerel Müdahale "Sosyal Belediyecilik" Karşılaştırmasında Eminönü ve Beşiktaş Belediyeleri Örnekleri", Onaylanmış Doktora Tezi, Marmara Üniversitesi, İstanbul

Kim, H.-Y. (2013). "Statistical Notes For Clinical Researchers: Assessing Normal Distribution (2) Using Skewness And Kurtosis", The Korean Academy of Conservative Dentistry, p. 52-54.

Koray, M., Topçuoğlu, A. (1995). Sosyal Politika, Ezgi Kitabevi, Bursa. Mardia, K. (1974). "Applications Of Some Measures Of Multivariate Skewness And Kurtosis In Testing Normality And Robustness Studies", The Indian Journal of Statistics, s. 115-128.

Mike, Raco- Imrie, R. (1999). "How New is the New Local Governance?" Transactions of the Institute of British Geographers; New Series, Vol. 24, No. 1;1999; s. 45-63

Negiz, N. (2011). "Sosyal Yardım ve Sosyal Hizmet Faaliyetleri Açısından Isparta Belediyesi: Farkındalık, Yararlanma ve Değerlendirme Açısından Bir Araştırma", Süleyman Demirel Üniversitesi İktisadi ve İdari Bilimler Fakültesi Dergisi Y., 2011, C.16, S.2, s.323-341.

Özdamar, K. (2003). Modern bilimsel araştırma yöntemleri. Eskişehir: Kaan Kitabevi.

Özdamar, K. (2004). Paket Programlar ile İstatistiksel Veri Analizi, Kaan Kitabevi.

Pektaş, Ethem K, (2010). Türkiye'de Sosyal Belediyecilik Uygulamaları ve Temel Sorunlar, Akademik İncelemeler Dergisi Cilt:5 Sayı:1

Seyyar, A. (2008). "Yerel Siyasetin Gelişiminde Sosyal Siyasetin Önemi"; Yerel Siyaset Dergisi; Sayı 26.

Sharma, S. (1976). Applied Multivariate Techniques, JohnWiley\& Sons. Inc.

Taşçı, F. (2017). Türkiye' de Sosyal Politika Ve Dönüşüm: Zihniyet, Aktörler, Uygulamalar, Seta, Siyaset, Ekonomi Ve Toplum Araştirmalari Vakfi.

Toprak, Z. (1988). Kent Yönetimi ve Politikası, Akevler Akdeniz Bilimsel Araştırma Merkezi Yayınları No:3 (İkinci Baskı), İzmir. 
Torjman, S., Leviten, R. Eric, (2003). "The Social Role Of Local Government", The Caledon Institute of Social Policy.

Walsh, M., Stephens, P., Moore, S. (2000). Social Policy and Welfare; Steanley Thornes ltd; Cheltenham.

Uyar, H. "Türkiye'de ve Dünya' da Yerel Yönetimler: Kısa Bir Tarihçe", Aydinlanma1923, Sayı 51, 2004. http://kisi.deu.edu.tr/hakki.uyar/6.pdf

Yılmazer, A. “Belediye Yöneticilerinin İş Ahlâkı Ve Sosyal Sorumluluğa Yönelik Tutumlarının İncelenmesi: Adapazarı Büyükşehir Ve Merkez Belediyesinde bir Araştırma"; ,s. 311-324 http://www.etikturkiye.com/etik/yerel/3AydinYilmazer.pdf, 15.02.2010

\section{Kaynakça Bilgisi / Citation Information}

Koçak, O., Arslan, H. \& Eti, S. (2017). Belediyelerde Sosyal Politika Uygulamaları Ve Pendik Belediyesi Örneği , OPUS - Uluslararası Toplum Araştırmaları Dergisi, 7(12), 119-144. 